\title{
Brown muscle disease (BMD), an emergent pathology affecting Manila clam Ruditapes philippinarum in Arcachon Bay (SW France)
}

\author{
Cécile Dang ${ }^{1, *}$, Xavier de Montaudouin ${ }^{1}$, Patrice Gonzalez ${ }^{1}$, \\ Nathalie Mesmer-Dudons ${ }^{1}$, Nathalie Caill-Milly ${ }^{2}$ \\ ${ }^{1}$ Université Bordeaux 1, CNRS, EPOC, UMR 5805, Station Marine d'Arcachon, 2 rue du Pr Jolyet, 33120 Arcachon, France \\ ${ }^{2}$ Laboratoire Ressources Halieutiques Aquitaine, IFREMER, 1 allée du Parc Montaury, 64600 Anglet, France
}

\begin{abstract}
We describe an emerging pathology, brown muscle disease (BMD), which specifically affects the Manila clam Ruditapes philippinarum in Arcachon Bay (France). BMD induces a transformation of the posterior adductor muscle, which becomes infused by conchiolin and calcified, reducing the ability of clams to bury. The disease affects both types of muscular tissue, with striated muscle becoming affected to a higher degree than smooth muscle. Two indices were created to quantify the symptoms: the Muscle Print Index, used for empty and live shells, and the Final Disease Index, utilized for live clams only. Histological sections were made and observed under light microscopy to examine the muscular damage and to investigate a causal agent. Sections revealed an important inflammatory response with a large invasion of hemocytes into tissues and a heavy necrosis of muscular fibers. Additionally, molecular biology analyses were carried out to search for bacteria and protozoan agents using generic primers. In both histological and molecular assays, bacteria and protozoans were discounted. We monitored 4 sites scattered around the bay over 2 yr. The mean prevalence was $<12 \%$ without seasonal variation in 3 sites against $30 \%$ and a winter peak in 1 site. The latter site was accurately surveyed and revealed that clams at the sediment surface (abnormal position) were affected 3 times more frequently than buried clams (normal position).
\end{abstract}

KEY WORDS: Brown muscle disease - Clam - Ruditapes philippinarum · Adductor muscle . Pathology $\cdot$ Light microscopy

\section{INTRODUCTION}

The Manila clam Ruditapes philippinarum is one of the most fished and farmed bivalve mollusks in the world. This species originates from the Indo-Pacific region (Ponurovsky \& Yakovlev 1992). Since the beginning of the 20th century, it has been introduced in different parts of the world with the Pacific oyster Crassostrea gigas seeds (Flassch \& Leborgne 1992). In Europe, $R$. philippinarum was first introduced for culture purposes to France in 1972 and later to England, Spain and Italy (Flassch \& Leborgne 1992). Within a few years this species had established natural populations in these European countries, particularly along the French Atlantic coast. It was introduced to Arcachon Bay (SW France) in 1980 where it rapidly escaped from parks, colonized seagrass Zostera noltii beds and underwent intensive exploitation by fishermen. In 2006, Arcachon Bay harbored the most important stock of Manila clams in France (7600 metric tonnes, t) and ranked first in terms of national production $\left(450 \mathrm{t} \mathrm{yr}^{-1}\right)$ (Caill-Milly et al. 2006).

Many infectious agents can infect the Manila clam, but the main pathologies affecting this bivalve are Brown Ring Disease (BRD) (Paillard 1992, 2004) and perkinsosis (Fouche et al. 1997, Ngo \& Choi 2004, Villalba et al. 2004). BRD is induced by the bacterium Vibrio tapetis which disrupts the production of the perios- 
tracal lamina and causes an obvious abnormal conchiolin deposit on the inner side of the shell, forming a characteristic brown ring (Paillard 1992, Paillard \& Maes 1995a,b). This disease led to mass mortalities in Brittany (NW France) in 1987 and decimated stocks of cultured clams (Paillard 2004). Subsequently, BRD was observed along the French Atlantic coast and in other countries including Spain, Ireland, England, Italy and Korea (Paillard 2004, Park et al. 2006). Perkinsosis, caused by the protozoan Perkinsus sp. affects numerous molluscan species all over the world and can lead to mass mortalities (Azevedo 1989, Burreson \& Ragone Calvo 1996, Goggin 1996, Da Ros et al. 1998, Park \& Choi 2001, Leite et al. 2004, Cremonte et al. 2005, Villalba et al. 2005). In Korea, this parasite has been the cause of a severe decrease in clam populations since 1993 (Park \& Choi 2001). Previous studies in Arcachon Bay revealed that clams could be infected by brown ring disease, perkinsosis (Lassalle et al. 2007) and also by digenean trematodes (de Montaudouin et al. 2000). However, prevalence and infection intensity were relatively low.

Mortalities have been evident in Arcachon Bay in recent years, particularly during winter. A preliminary study revealed a previously undescribed necrosis of the posterior adductor muscle. Macroscopic diagnosis under stereomicroscope eliminated the possibility that macroparasites such as Polydora spp. (annelid), Cliona spp. (sponges) and trematodes were involved. As the posterior muscle was visually affected by the disease, we only considered this tissue in our study. Histopathological analysis of clam adductor posterior muscles has been in progress in epizootiotopes since November 2005. The purpose of the present study was to describe the pathology of the disease designated herein as 'Brown Muscle Disease' (BMD) and to monitor temporal variations over a 2 yr survey program. Preliminary investigations of etiological agents are also included.

\section{MATERIALS AND METHODS}

Study area. Arcachon Bay $\left(44^{\circ} 40^{\prime} \mathrm{N}, 1^{\circ} 10^{\prime} \mathrm{W}\right)$ is a $156 \mathrm{~km}^{2}$ semi-sheltered lagoon in the southwest of France (Fig. 1). Tidal flats represent $110 \mathrm{~km}^{2}$, with $70 \%$ covered by Zostera noltii seagrass beds and colonized by the Manila clam (Caill-Milly et al. 2003). Arcachon Bay is subject to both oceanic and continental influences, with a semi-diurnal macrotidal rhythm. External neritic waters enter through 2 channels situated at the southwest end of the lagoon and meet with freshwater inputs, principally from the Eyre River (Fig. 1). Clams are usually situated in the mid intertidal zone but can be found from $2.75 \mathrm{~m}$ above the 0

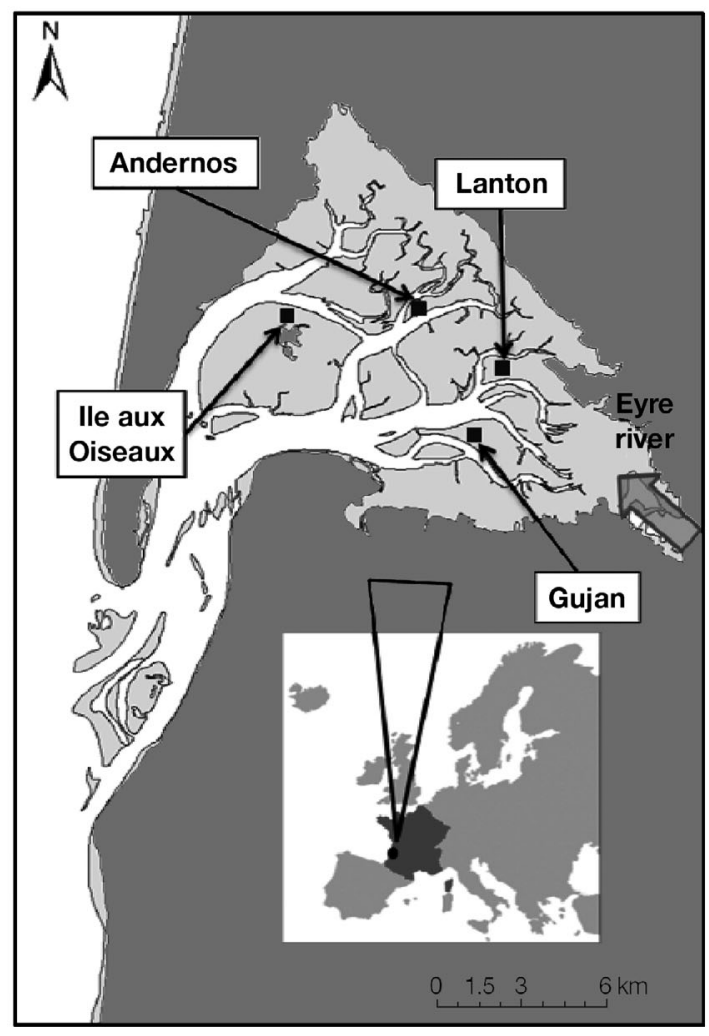

Fig. 1. Location of sampling stations in the tidal flats of Arcachon Bay, SW France

of low tide (Cottet et al. 2007) to the tidal channel. The 2 yr temporal survey was carried out at 4 different sites (Fig. 1) where the seagrass bed generally flourished on muddy sediments.

Environmental parameters. From November 2005 until November 2007 the sediment temperature was measured every hour using in situ electronic devices. Sediment granulometry was determined using a laserdiffractometer (Malvern Master Sizer). This device uses a laser beam to determine the properties of diffraction and diffusion of particles. Water salinity data were provided by IFREMER Arcachon.

Histological assay. Ten clams were collected for each of the 3 disease stages, healthy, intermediate and advanced. Posterior adductor muscles were dissected, fixed in Bouin's fixative, dehydrated in ethanol followed by xylene, embedded in a paraffin-wax block and cut in a microtome. Sections (5 $\mu \mathrm{m}$ thick) were first deparaffinized, then rehydrated and finally stained with May-Grunwald-Giemsa. Histological sections of Ruditapes philippinarum muscle were observed by light microscopy for diagnosis of pathological alterations.

Molecular biological assays: DNA extraction and PCR analysis. In order to attempt the identification of a 
pathogen agent, DNA was extracted from the muscles of 5 infected clams and 5 healthy clams. Muscles were incubated in an extraction buffer $(0.1 \mathrm{M} \mathrm{NaCl}, 20 \mathrm{mM}$ EDTA, $0.3 \mathrm{M}$ Tris) with proteinase $\mathrm{K}\left(0.2 \mathrm{mg} \mathrm{ml}^{-1}\right)$ and sodium dodecyl sulfate $(0.6 \%)$ until complete digestion. Deproteinisation was then carried out using phenol:chloroform:isoamyl alcohol (25:24:1) and chloroform, followed by a precipitation of nucleic acids $(\mathrm{AcNa}, 3 \mathrm{M}, 0.1 \times$ vol; absolute ethanol, $2 \times$ vol). The resulting pellet was washed in $70 \%$ ethanol and resuspended in $\mathrm{H}_{2} \mathrm{O}$ with RNase $\left(20 \mu \mathrm{g} \mathrm{ml} \mathrm{m}^{-1}\right)$. Extraction efficiency was verified by migration of DNA isolated in a $1 \%$ agarose Tris Acetic acid EDTA (TAE) buffer gel and stained with ethidium bromide $\left(0.2 \mu \mathrm{g} \mathrm{ml}^{-1}\right)$. The universal primer pair for eukaryotic 18S rDNA CAS1S (GGAATTGACGGAAGGGCACC)/CAS2 (ACGGGC GGTGTGTACAAAGG) was used to control the quantity of DNA as well as the presence of inhibitory factors (Le Roux et al. 1999). Negative control was $\mathrm{H}_{2} \mathrm{O}$. After one hundredth dilution of our samples, the expected PCR product was obtained for reference genes.

Occurrence of bacteria and protozoans was investigated using universal primers described for these organisms. The amplification of bacterial DNA was carried out with the primer pair Eubu 1492 R (TACGGTTACCTTGTTACGACTT)/Eubu 27 F (AGAGTTTG ATCATGGCTCACA) (Lane 1991) and the protozoan's DNA amplification with the primers $18 \mathrm{~S}$ Euk $581 \mathrm{~F}$ (GTGCCAGCAGCCGCG) / 18 S Euk 1134 R (TTTA AGTTTCAGCCTTGCG) (Carnegie et al. 2003).

PCR reactions were performed in $50 \mu$ l containing $2 \mu \mathrm{l}$ of isolated DNA, $0.5 \mu \mathrm{l}$ of each universal primer $(100 \mu \mathrm{M}), 3 \mu \mathrm{l}$ of $\mathrm{MgCl}_{2} 25 \mathrm{mM} ; 10 \mu \mathrm{l}$ of $5 \times$ Go Taq flexi buffer; $1 \mu \mathrm{l}$ of dNTP (10 mM), $0.2 \mu \mathrm{l}$ of Taq polymerase

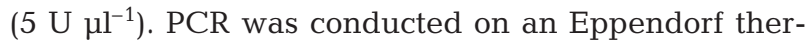
mocycler and had the following profile for bacteria: $95^{\circ} \mathrm{C}$ for $1 \mathrm{~min} ; 35$ cycles of $95^{\circ} \mathrm{C}$ for $1 \mathrm{~min}, 48^{\circ} \mathrm{C}$ for $1 \mathrm{~min}, 72^{\circ} \mathrm{C}$ for $1 \mathrm{~min}$ and $72^{\circ} \mathrm{C}$ for $5 \mathrm{~min}$, and for protozoans: $95^{\circ} \mathrm{C}$ for $1 \mathrm{~min} ; 35$ cycles of $95^{\circ} \mathrm{C}$ for $1 \mathrm{~min}$, $62^{\circ} \mathrm{C}$ for $1 \mathrm{~min}, 72^{\circ} \mathrm{C}$ for $1 \mathrm{~min}$ and $72^{\circ} \mathrm{C}$ for $5 \mathrm{~min}$. Positive controls were Escherichia coli and Perkinsus sp. for bacteria and protozoan primers respectively, and negative controls were $\mathrm{H}_{2} \mathrm{O}$. PCR products were analyzed on a $1 \%$ agarose TAE buffer gel stained with ethidium bromide.

Temporal survey. One hundred adult clams (30 to $40 \mathrm{~mm}$ ) were collected monthly from December 2005 to February 2007 at the Ile aux Oiseaux and Gujan sites, and from December 2005 to November 2007 at Andernos and Lanton (Fig. 1). Clams were collected from their normal, i.e. buried, position. Individuals were opened and muscle prints were observed on the inner side of the shells under a stereomicroscope to quantify the pathology. The term 'muscle print' defines the muscle scar with pieces of affected calcified muscle still attached to the shell (see Fig. 2a). The surface of the muscle print was divided into 4 equal sectors. The Muscle Print Index (MPI) was used to designate the surface colonized by the brown muscle print on a scale of 0 to 4 as follows: 0 (healthy), $1(0-25 \%), 2(25-50 \%)$, $3(50-75 \%)$ and $4(75-100 \%)$. When both valves displayed different pathology indices, the highest category was selected to characterize the stage of BMD. The advantage of MPI was that it enabled us to measure the pathology intensity on empty shells that were kept dry. Prevalence and MPI were determined monthly at each site.

Lanton survey. Ruditapes philippinarum, like many bivalves, possesses 1 anterior and 1 larger posterior adductor muscle. Each muscle consists of a smooth and a striated tissue (Fig. 2). At the most affected of the 4 sites (Lanton), a specific survey was carried out to distinguish the pathology intensity in both muscular tissues and both positions of clams, buried (normal) or at the surface (abnormal). Buried $(\mathrm{N}=50)$ and unburied $(\mathrm{N}=50)$ clams were collected monthly from November 2006 to April 2007.

The volume of each affected muscular tissue was evaluated. Each tissue was evaluated twice on a scale of 0 to 4 to describe (1) the affected depth and (2) the affected surface. For each tissue, the depth value was multiplied by the surface value to obtain a volume value from 0 (healthy) to 16 (totally diseased). As for the MPI, the highest value for each striated and each smooth tissue was selected and, thus, 2 Final Disease Indices (FDI) were obtained for each clam. These FDIs give a better diagnosis of the pathology but can be applied only when muscle tissues are still present. Four FDI stages were defined, based on the FDI values: Stage a (1-4), b (5-8), c (9-12) and d (13-16). Prevalence was calculated for buried and unburied clams.

Finally, in order to assess pathology specificity, other bivalves were collected and dissected between October 2006 and May 2007. One hundred cockles Cerastoderma edule (23-36 mm) and 100 carpet shell clams Ruditapes decussatus (14-23 mm) were processed.

\section{RESULTS}

\section{Environmental parameters}

The environmental parameters displayed heterogeneity of the Manila clam habitat. Salinity and sediment temperature varied between sites and fluctuated yearly between 4 and 35 psu and between -2 and $44^{\circ} \mathrm{C}$, respectively (Table 1 ). The sediment grain-size is also variable between sites. The median was $163 \mu \mathrm{m}$ at Andernos, $78.5 \mu \mathrm{m}$ at Lanton, $97 \mu \mathrm{m}$ at Ile aux Oiseaux and $68.7 \mu \mathrm{m}$ at Gujan (Table 1). 
Table 1. Environmental variables characterizing the 4 sites in Arcachon Bay, SW France: median grain size $(\mu \mathrm{m})$, sediment temperature $\left({ }^{\circ} \mathrm{C}\right)$ and salinity (psu)

\begin{tabular}{|c|c|c|c|c|c|c|c|}
\hline \multirow[t]{2}{*}{ Site } & \multirow{2}{*}{$\begin{array}{c}\text { Sediment } \\
\text { grain size } \\
\quad(\mu \mathrm{m})\end{array}$} & \multicolumn{3}{|c|}{$\begin{array}{c}\text { Sediment } \\
\text { temperature }\left({ }^{\circ} \mathrm{C}\right)\end{array}$} & \multicolumn{3}{|c|}{ Salinity (psu) } \\
\hline & & Min. & Max. & Mean & Min. & Max. & Mean \\
\hline Andernos & 163.0 & -1.0 & 35.4 & 15.8 & 18.5 & 34.5 & 30.0 \\
\hline Lanton & 78.5 & -1.7 & 37.8 & 16.0 & 4.8 & 34.4 & 26.7 \\
\hline Ile aux Oiseaux & 97.0 & 0.2 & 37.9 & 16.1 & 12.1 & 34.8 & 29.6 \\
\hline Gujan & 68.7 & -0.2 & 43.7 & 16.1 & 4.8 & 34.4 & 26.7 \\
\hline
\end{tabular}

stage, the striated muscle was often the first and the most severely affected. The first gross sign of the disease was the appearance of one or several large yellowish nodules within the striated muscle and also of minute brown spots on the adductor muscle attachment. The nodules increased in size and the tissues became increasingly brown (conchiolin) and hard (calcified). First, the soft tissues of the muscle became brown (conchiolin)

\section{Clinical signs of BMD}

All disease signs were visible to the naked eye and BMD was only observed in the posterior muscle. Diseased clams exhibited pathological signs, such as muscle atrophy and degraded tissues. The muscle becomes progressively brown and hard (Fig. 2), the brown color being linked to the diffusion of conchiolin within the muscle. Calcification was assumed because of the positive reaction with $\mathrm{HCl}$. Three different macroscopic states of infection were noted: healthy, intermediate and advanced stages. In the intermediate

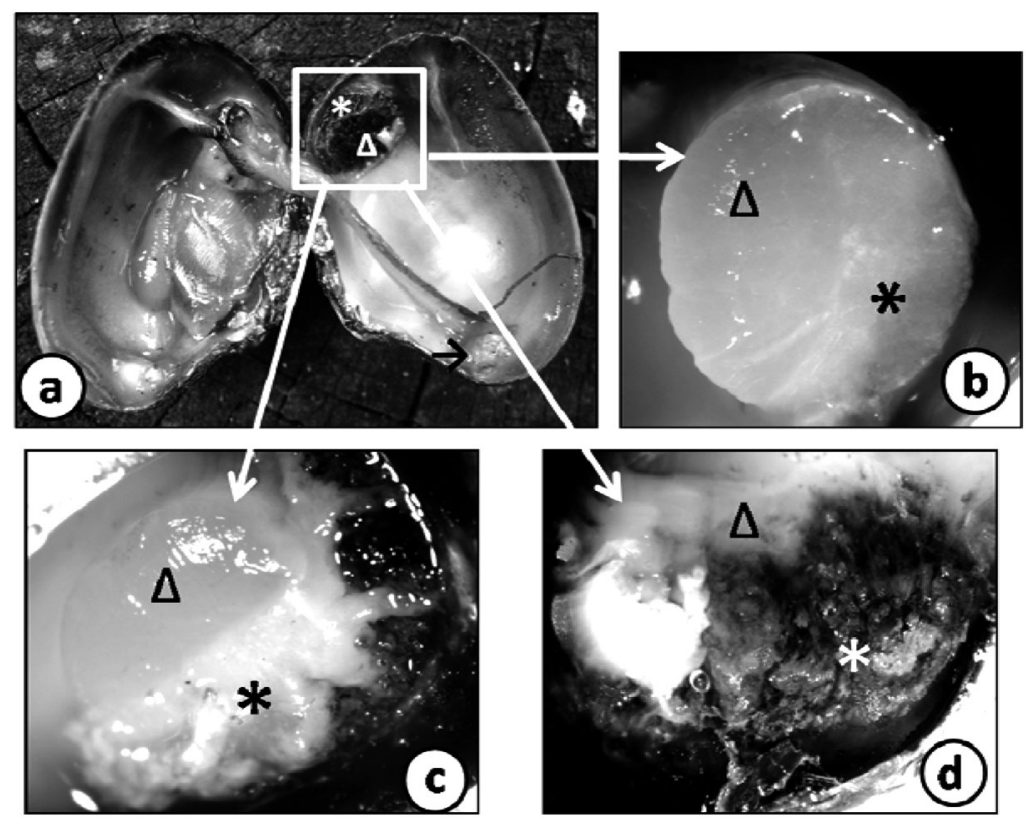

Fig. 2. Ruditapes philippinarum. External appearance of Manila clam posterior muscle (3 macroscopic stages) with the distinction between striated $(*)$ and smooth $(\Delta)$ muscles. (a) Whole clam with focus on 'muscle print' (muscle scar and attached remnant muscle tissues) showing a brown posterior muscle (Muscle Print Index, MPI = 4) (black arrow: anterior muscle, always normal); (b) healthy muscle (MPI =0); (c) intermediate stage with the beginning of the brown conchiolin infiltration and calcification. The striated muscle is the first to become affected (MPI = 2); (d) advanced stage with the striated muscle as well as a major part of the smooth muscle completely brown and calcified $(\mathrm{MPI}=4)$. For details of the MPI see 'Materials and methods' and in the next stage the muscle became hard, i.e. it calcified. BMD reduced the effective area of attachment of the adductor muscle to the shell. In the advanced stage, the smooth muscle was also modified and the striated muscle was completely brown and calcified as was the majority of the smooth muscle (Fig. 2). At the end, both muscular tissues were completely infused with conchiolin and calcified.

The survey of the Lanton site confirmed that the striated muscle was the first and the most infected of the 2 muscular tissues. Out of 600 analyzed clams, prevalence of BMD was $41.5 \%$ for smooth muscle and $48.7 \%$ for striated muscle. A percentage comparison test showed a significant difference between both muscles $(p<0.05)$. Stage a dominated in smooth muscle with $43 \%$ and Stage d prevailed in striated muscle with $38 \%$ (Fig. 3). The disease reached maximum intensity (Stage d) in $38 \%$ of clams for striated muscle compared with $20 \%$ in smooth muscle (Fig. 3). In the infected clams, 98\% of striated muscles were infected, while disease did not spread to the smooth muscle in around $16 \%$ of the clams.

\section{Histopathology}

The 3 macroscopic stages - healthy, intermediate and advanced - were used for histological investigations (Fig. 4). The severity of the muscular damage corresponded to the intensity of coloration (from yellow to brown) and to the hardness of the tissue. In the healthy stage, the muscular fibers of the striated muscle were organized normally and composed of several myofibrils (Fig. 4). In the intermediate stage, the striated muscle displayed disorganized necrotic muscular fibers with a loss of surface adherence between muscular 


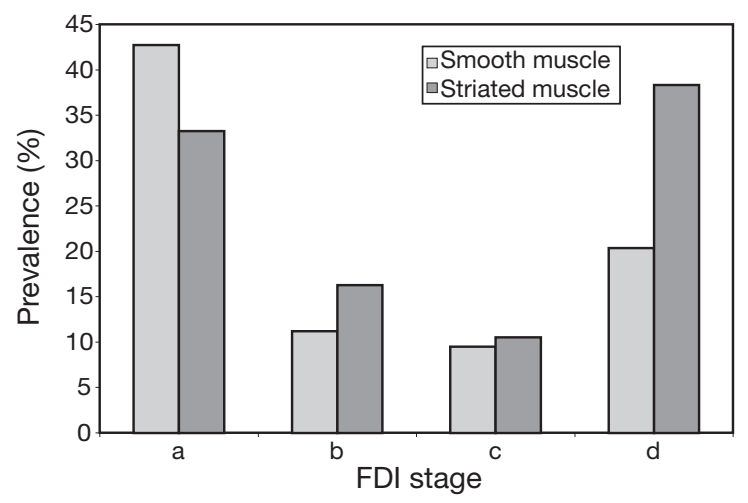

Fig. 3. Ruditapes philippinarum. Final disease index (FDI) for smooth and striated muscle at the Lanton site $(\mathrm{N}=600)$ cells, a loss of muscle bundle orientation and substantial atrophy. Muscular fibers disappeared and were progressively replaced by intense hemocytic infiltration (Fig. 4b,d). These hemocytes were composed of numerous basophilic granulations and consequently were assumed to be granulocytes (Fig. 4d). These cells possessed pathological peripheral pycnotic nuclei. Several granulocytes can amalgamate to improve the defense mechanism of clams. The intensity of granulocytic concentration differed within different degrees of tissue destruction, thus indicating the progression of the pathology. Between these defense cells, remnants of muscular tissues were present. The advanced stage of the pathology (Fig. 4c) is characterized by the total
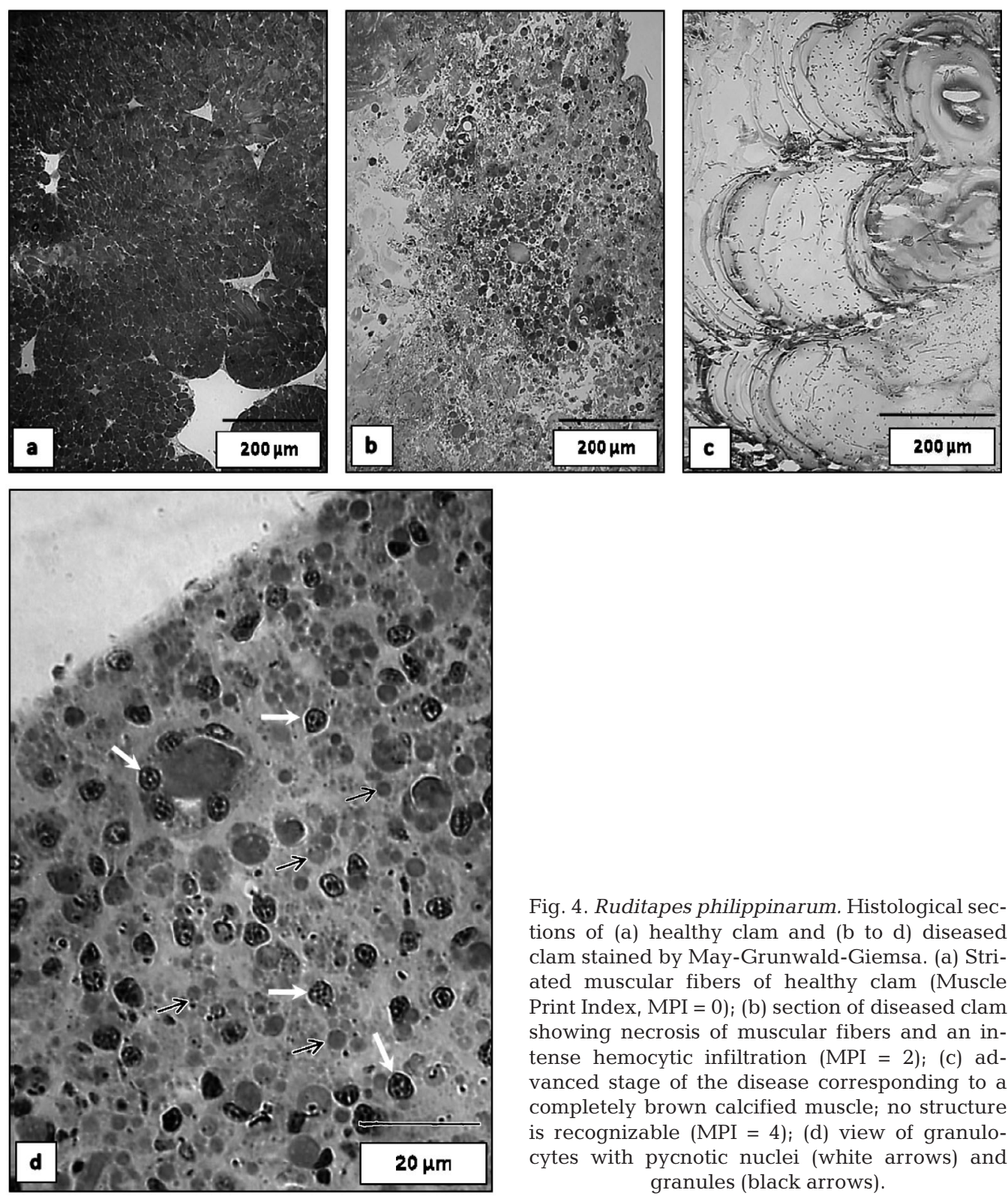

Fig. 4. Ruditapes philippinarum. Histological sections of (a) healthy clam and (b to d) diseased clam stained by May-Grunwald-Giemsa. (a) Striated muscular fibers of healthy clam (Muscle Print Index, MPI = 0); (b) section of diseased clam showing necrosis of muscular fibers and an intense hemocytic infiltration (MPI $=2$ ); (c) advanced stage of the disease corresponding to a completely brown calcified muscle; no structure is recognizable (MPI $=4$ ); (d) view of granulocytes with pycnotic nuclei (white arrows) and granules (black arrows). 
destruction of the muscle, which was completely necrotized. Neither muscular fibers nor cells such as hemocytes were observed; all functional structures had disappeared due to calcified necrosis (Cabanne \& Bonenfant 1986). Thus, no bacterial, protozoan, metazoan or fungal organisms were observed in these sections.

\section{Molecular biological assays}

With respect to the occurrence of bacteria, no PCR products were obtained in either healthy or infected muscles, while a band was observed with the positive control. Similar results were achieved for protozoans and some fungus species analyses. Consequently, PCR did not provide evidence of bacteria, protozoans or some fungi.

\section{Temporal survey}

Between December 2005 and November 2007, prevalence of BMD was between 0 and $48 \%$, and was significantly different between sites (1-way ANOVA, arc$\sin \sqrt{ } p$, where $p$ is prevalence, transformed data, $\mathrm{p}<$ 0.05) (Fig. 5). A Tukey test distinguished 3 groups ( $<<$ 0.05): (1) Andernos, (2) Gujan and Ile aux Oiseaux, and (3) Lanton. Andernos appeared to be the least infected site with a mean prevalence of $4.5 \%$. Ile aux Oiseaux and Gujan formed a second group with a mean BMD prevalence of $12 \%$. No seasonal variations were observed in these 3 sites, in contrast to Lanton where the mean prevalence was $30.4 \%$, with 2 significant peaks $(p<0.05)$ during cold periods in February 2006 and in November 2006 (prevalence of $48 \%$ ).

The intensity of the pathology was assessed by means of the MPI (Fig. 5). In contrast to prevalence, intensity was not highest during cold months. In Andernos, where the lowest prevalence was observed, MPI Stages 1 and 2 dominated with a respective mean of 31 and $34.3 \%$. No seasonality was observed for prevalence, but the highest values of Stage 4 were found in March 2006 (42.8\%), in July 2006 (33.3\%) and in June $2007(28.5 \%)$. Stages 1 and 2 prevailed in Gujan with 32.8 and $33.6 \%$ respectively. No important variations were shown, but Stage 4 was present each month during sampling, with the exception of September 2006 and February 2007. The same dominance was observed at Ile aux Oiseaux: Stage 1 (35.3\%), 2 $(26.8 \%), 3(17.1 \%)$ and $4(20.8 \%)$. Lanton differed from the other sites with the highest percentage of Stage 4 $(28.9 \%)$. The high prevalence observed in Lanton during winter was not correlated with an increase of the MPI stages.

\section{Lanton survey}

The prevalence of infected clams was significantly higher $(p<0.05)$ in surface clams $(78.3 \%)$ than in buried clams $(26.8 \%)$. Furthermore, the MPI stages were higher in unburied than buried clams (Fig. 6). BMD reached maximum intensity in Stage 1 for buried clams $(33.3 \%)$ and in Stage 4 for surface clams $(58.9 \%)$.

BMD affected the 2 muscles differently, depending on the clam's living position. Our observations of BMD prevalence in both muscle tissues reinforced the findings of the histological and macroscopic anlyses, with the striated being the most heavily infected muscle. For smooth muscle, disease prevalence was $19 \%$ in buried clams compared with $64 \%$ in surface clams. For striated muscle, prevalences were $27 \%$ in buried clams compared with $71 \%$ in surface clams. In both cases (surface and buried), BMD prevalence was significantly different $(p<0.05)$ between smooth and striated muscles and also between surface and buried clams for each muscle.

Neither the 100 sympatric cockles Cerastoderma edule nor the 100 Ruditapes decussatus clams were infected by BMD.

\section{DISCUSSION}

Manila clam mortalities in Arcachon Bay were associated with high prevalence of a characteristic and visible (to the naked eye) sign: an important atrophy and a hardening of the adductor muscle which becomes progressively infused by brown conchiolin and calcified. BMD leads to the total destruction of the muscle in advanced stages of the disease. BMD has never been described in any clam in any part of the world, but similar signs were described in the Japanese pearl oyster Pinctada fucata martensii (Miyazaki et al. 1999). The disease affected the mantle lobe, the foot, cardiac and adductor muscles which became dark, although no hardening or calcification were reported. This disease was responsible for mass mortalities and drastic economic losses (Miyazaki et al. 1999). Another disease called Syndrome 85 was described in the blacklip pearl oyster Pinctada margaritifera and caused mass mortalities in 1985 in French Polynesia (Comps et al. 1999, 2001). In addition to producing the same symptoms previously described in the Japanese pearl oyster for the adductor muscle, Syndrome 85 also affected the shell by causing a brown deposit of organic matter on the inner side of valves. Organic deposits in the shell are usually the sign of a reaction stimulated by a wound, a parasite, debris or hemocytes (Perkins 1996). Currently it seems that BMD only 


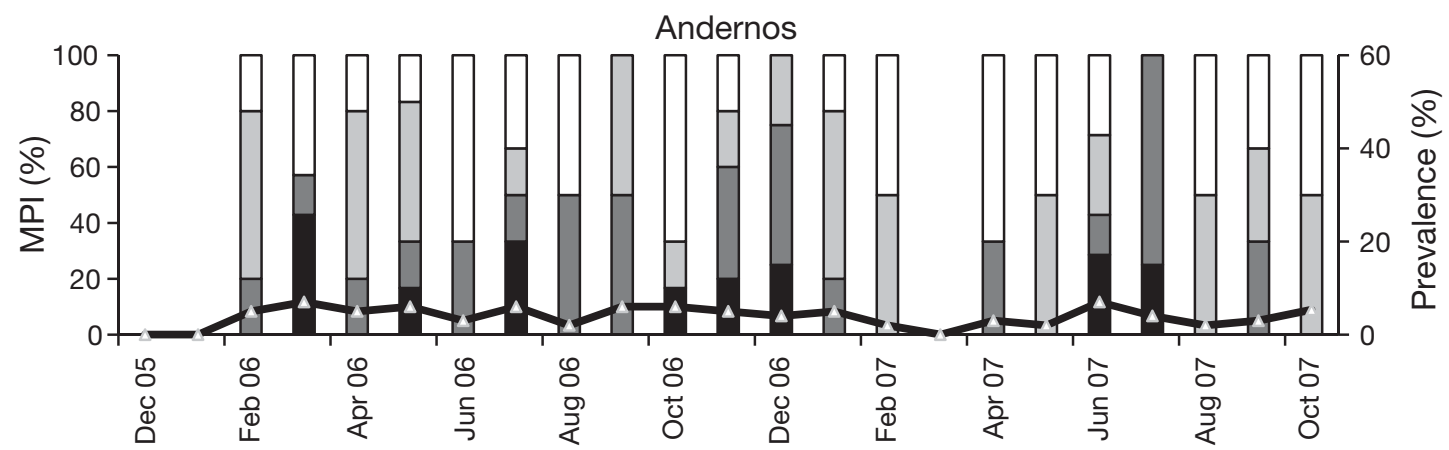

Lanton
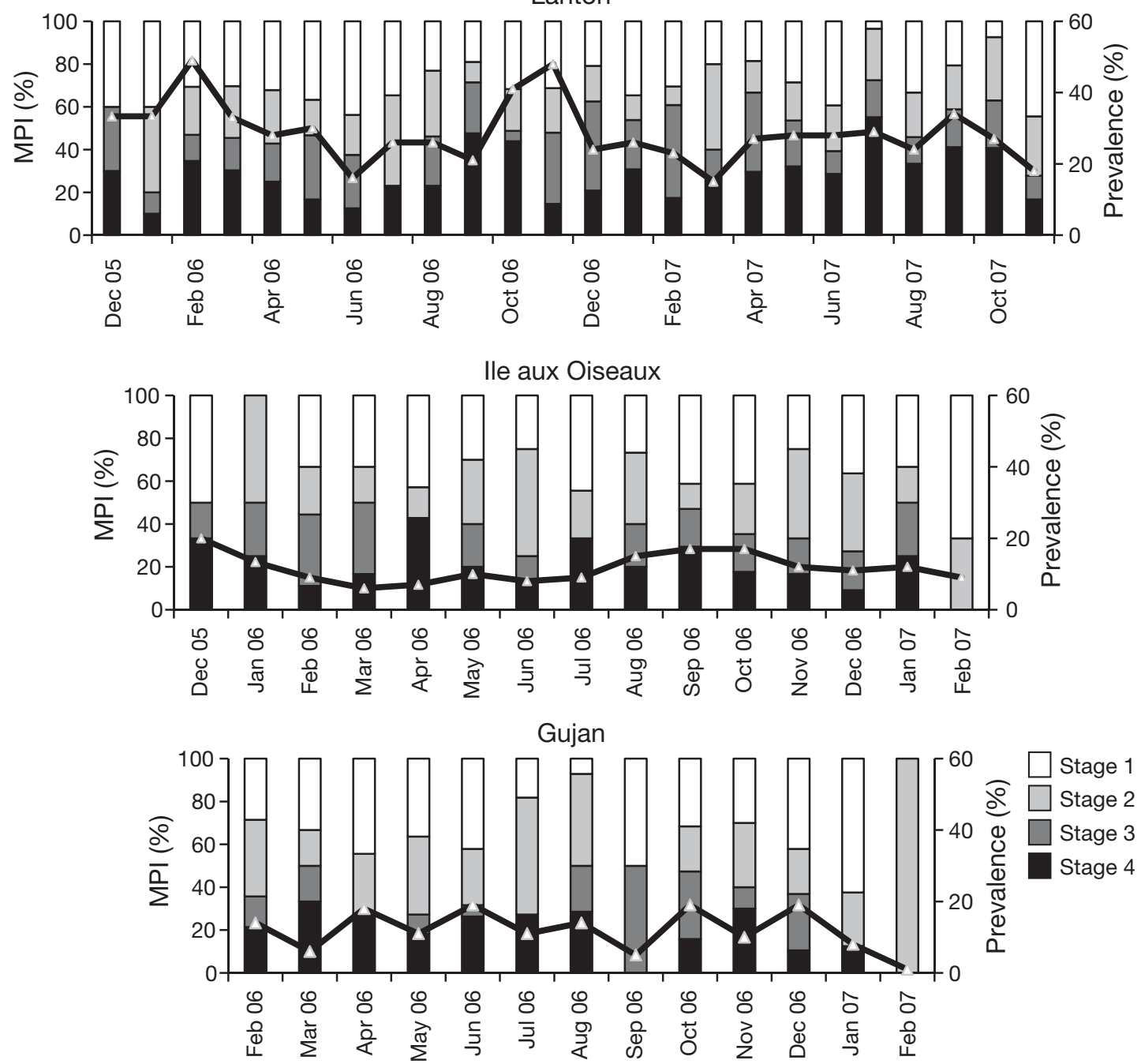

Fig. 5. Evolution of the prevalence (-) and the muscle print index (MPI) with time in the 4 sites. For details of Stages 1 to 4 see 'Materials and methods'

affects the posterior muscle of Manila clams in Arcachon Bay, and even if some similarities were found with oyster diseases, this pathology is new because of the total muscle transformation, its brown conchiolin infusion and its progressive calcification. BMD does not resemble any other known disease in Ruditapes philippinarum. Muscle fibers were, however, extensively necrotized and degenerated, as in the Japanese pearl oyster disease (Miyazaki et al. 1999).

Because there appeared to be disturbances in the activity of the adductor muscle, this muscular damage disrupted the life cycle of the clams by inhibiting the 


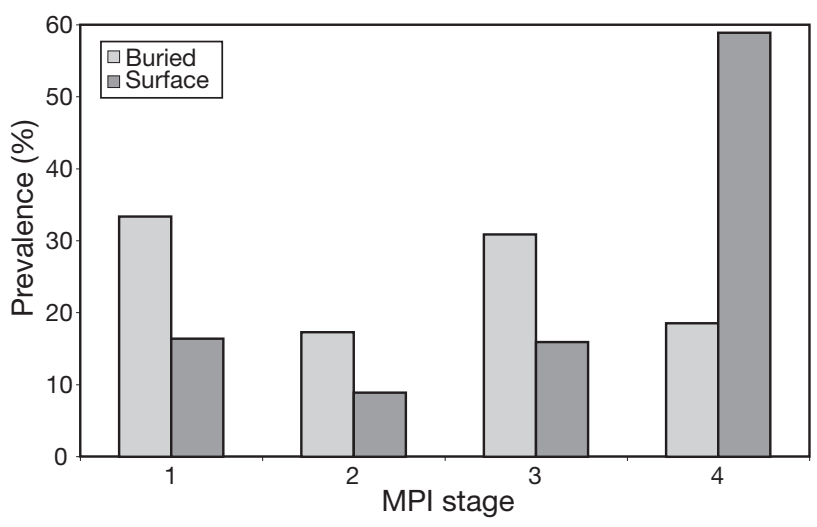

Fig. 6. Muscle print index (MPI) for buried and surface clams from the Lanton site $(\mathrm{N}=600)$. For details of Stages 1 to 4 see 'Materials and methods'

valve opening and closing processes. These functional perturbations could disturb feeding and respiratory activities. Clams were unable to remain buried and migrated to the surface of the sediment; this phenomenon led to their death. BMD is the most important pathology in Arcachon Bay since the introduction of the Manila clam.

Clams from the Lanton site revealed a seasonality in the occurrence but not in the intensity stages (MPI) of BMD. Prevalence was higher during cold periods, and 2 winter peaks were observed. The decrease in prevalence from February 2006 to June 2006 and from November 2006 to March 2007 indicated either tissue restoration (unlikely) or mortality events which were confirmed by our field observations (considerable increase in surface clams) in the 4 sampled sites, including areas of high mortality. This would mean that the disease did not necessarily have to be at an advanced MPI stage for death to result. BMD may induce a weakening of the whole clam and, consequently, affected animals are more sensitive to environmental conditions such as cold temperatures in winter or pathogenic agents. At Lanton, prevalence of BMD in buried clams was relatively high at $27 \%$, but still lower than prevalence in clams collected at the surface $(79 \%)$. The ascent of bivalves toward the surface is often considered as the prelude to death (Desclaux et al. 2002). It seemed that BMD was the first cause of the vertical migration of clams toward the sediment surface, although this may be accelerated by a variety of factors, including physical factors such as cold temperatures in winter and/or temperature variations due to tidal rhythms (Lauckner 1987), or high clam densities (Richardson et al. 1993).

The principal sign of BMD was that the posterior adductor muscle was visiby affected; the anterior always remained macroscopically healthy. The poste- rior muscle was located nearest the sediment surface and therefore was more vulnerable to certain pathogenic agents or environmental variations. Although a few other species of bivalves lived in sympatry with Ruditapes philippinarum (e.g. Cerastoderma edule and $R$. decussatus), none of them were affected by BMD, which consequently appears to be a species-specific disease. Symptoms varied between the two types of muscle tissue, with the striated muscle being the first and most severely infected. Striated tissue was likewise situated nearest the surface in the clams' living position, and this was certainly important with respect to contamination by a causal agent and/or for the development of the pathology. The disease was subsequently propagated to the smooth muscle. The 2 tissues each have a distinct function: the striated muscle is responsible for quick pulses of the valves, whereas the smooth muscle permits the slow movement of valves and holds the valves closed. Consequently, BMD affected valve activity and clam mobility. The presence of sediment inside clams showed that this disease also altered the hermeticism of the valves, which could be conducive to penetration by opportunist pathogens such as fungal, bacterial, viral or protozoan organisms.

BRD and perkinsosis were analyzed, but no significant differences were found between buried and unburied clams (authors' unpubl. data). Even though these 2 pathologies are known to severely affect clams in other geographical areas, they do not appear to affect clam populations in Arcachon Bay. Microscopy and molecular biology analyses did not identify any etiological agents. PCR analysis excluded the presence of bacteria, protozoans and some fungi, as confirmed by the histological observations.

There are few pathogens which affect the muscles of mollusks; of these, the association between a protozoan Haplosporidium sp. and a Rickettsia-like prokaryote in Withering Syndrome affects the foot of abalone causing the reduction of muscular fibers, the loss of bundle orientation and finally, atrophy and necrosis (Balseiro et al. 2006). Another pathogen, a shell disease called 'maladie du pied', and caused by a fungus similar to Ostracobable implexa, has affected the adductor muscles of Ostrea edulis and Crassostrea angulata in Europe since 1887 (Alderman \& Jones 1971, 1997). This disease begins with small rounded black lumps in the adductor muscle attachment area, which progressively enlarge and become coalescent. Eventually, the muscle attachment may become a raised boss, often with incomplete layers of more calcified shell overlying it (Alderman \& Jones 1971, 1997). The signs of BMD may resemble shell disease and Japanese pearl oyster diseases. Some viruses can alter muscles, for example in the cephalopod Octopus vul- 
garis, by inducing tumors which disturb the functioning of muscle tentacles (Rungger et al. 1971).

The causative agent of BMD might be a fungus or a virus. The signs of disease were closer to those of Japanese pearl oyster diseases for which Miyazaki (et al. 1999) demonstrated that the causal agent was a non-enveloped virus. This author assumed that this virus was the cause of all muscular damage: hemocytes infiltration, tissue necrosis, degeneration of muscle fibers and, eventually, oyster mortalities. Furthermore, paraspherical virus-like particles were observed in histological sections of oysters affected by Syndrome 85 and were considered highly likely to be the causal agent of the disease (Comps et al. 1999, 2001). In this context, further investigations should focus on the observation of affected muscle tissues and use transmission electron microscopy to detect virus-like particles, if present. Furthermore, to better understand the whole pathological process, other organs should be processed by light microscopy. Questions related to transmission of the disease within the wild bivalve population should also be addressed in future research on BMD.

Acknowledgements. The authors are particularly grateful to P. Lebleu, F. Prince and J. J. Joubert for their assistance in the field, R. B. Carnegie for his help with protozoan primers, J. R. Bonami for his support in histological interpretation and C. Bolton for reviewing the English. Many thanks to S. Saez, F. Huchin and M. Basterretxea for assistance in and ex situ. This study was partly financed by Conseil Général Gironde and Agence Nationale de la Recherche (Projet Multistress). C.D. was financed by Fonds Communs Aquitaine Euskadi.

\section{LITERATURE CITED}

Alderman DJ, Jones EBG (1971) Shell disease of oyster. Fish Investig 26:1-19

Alderman DJ, Jones EBG (1997) Shell disease of Ostrea edulis. Nature 216:797-798

Azevedo C (1989) Fine structure of Perkinsus atlanticus n. sp. (apicomplexa, Perkinsea) parasite of the clam Ruditapes decussatus from Portugal. J Parasitol 75:627-635

Balseiro P, Conchas RF, Montes J, Gomez-Leon J, Novoa B, Figueras A (2006) Comparison of diagnosis techniques for the protozoan parasite Bonamia ostreae in flat oyster Ostrea edulis. Aquaculture 261:1135-1143

Burreson EM, Ragone Calvo LM (1996) Epizootiology of Perkinsus marinus disease of oysters in Chesapeake Bay, with emphasis on data since 1985. J Shellfish Res 15:17-34

Cabanne F, Bonenfant JL (1986) Anatomie pathologique: principes de pathologie spéciale et d'aetopathologie, 2nd edn. Les Presses de l'Université Laval du Québec. Maloine Éditeur, Paris

Caill-Milly N, de Casamajor MN, Lissardy M, Sanchez F, Morandeau G (2003) Evaluation du stock de palourdes du bassin d'Arcachon - Campagne 2003. IFREMER, Bidart

Caill-Milly N, Duclercq B, Morandeau G (2006) Campagne d'évaluation du stock de palourdes du bassin d'Arcachon. IFREMER
Carnegie RB, Meyer GR, Blackbourn J, Cochennec-Laureau N, Berthe FCJ, Bower SM (2003) Molecular detection of the oyster parasite Mikrocytos mackini, and a preliminary phylogenetic analysis. Dis Aquat Org 54:219-227

Comps M, Herbaut C, Fougerouse A (1999) Virus-like particles in pearl oyster Pinctada margaritifera. Bull Eur Assoc Fish Pathol 19:85-88

Comps M, Herbaut C, Fougerouse A, Laporte F (2001) Progress in pathological characterization of Syndrome 85 in the black-lip pearl oyster Pinctada margaritifera. Aquat Living Resour 14:195-202

Cottet M, de Montaudouin X, Blanchet H, Lebleu P (2007) Spartina anglica eradication experiment and in situ monitoring assess structuring strength of habitat complexity on marine macrofauna at high tidal level. Estuar Coast Shelf Sci 71:629-640

Cremonte F, Figueras A, Burreson EM (2005) A histopathological survey of some commercially exploited bivalve molluscs in northern Patagonia, Argentina. Aquaculture 249:23-33

- Da Ros L, Marin MG, Nesto N, Ford SE (1998) Preliminary results of a field study on some stress-related parameters in Tapes philippinarum naturally infected by the protozoan Perkinsus sp. Mar Environ Res 46:249-252

de Montaudouin X, Kisielewski I, Bachelet G, Desclaux C (2000) A census of macroparasites in an intertidal bivalve community, Arcachon Bay, France. Oceanol Acta 23: $453-468$

> Desclaux C, de Montaudouin X, Bachelet G (2002) Cockle emergence at the sediment surface: 'favourization' mechanism by digenean parasites? Dis Aquat Org 52:137-149

Flassch JP, Leborgne Y (1992) Introduction in Europe, from 1972 to 1980, of the Japanese manila clam (Tapes philippinarum) and effects on aquaculture production and natural settlement. ICES Mar Sci Symp 194:92-96

Fouche D, Renault T, Le Deuff RM, Grizel H (1997) Etat des connaissances sur la pathologie chez les mollusques bivalves. IFREMER R. INT.DEL /97.01/, La Tremblade. Also available at: www.ifremer.fr/docelec/doc/1997/ rapport-1923.pdf

> Goggin CL (1996) Effect of Perkinsus olseni (Protozoa, Apicomplexa) on the weight of Tridacna crocea (Mollusca, Bivalvia) from Lizard Island, Great Barrier Reef. Aquaculture 141:25-30

Lane DJ (1991) 16S/23S rRNA sequencing. In: Stackebrandt E, Goodfellow M (eds) Nucleic acid techniques in bacterial systematics. John Wiley, Chichester, p 115-175

> Lassalle G, de Montaudouin X, Soudant P, Paillard C (2007) Parasite co-infection of two sympatric bivalves, the Manila clam (Ruditapes philippinarum) and the cockle (Cerastoderma edule) along a latitudinal gradient. Aquat Living Resour 20:33-42

Lauckner G (1987) Ecological effects of larval trematode infestation on littoral marine invertebrate populations. Int J Parasitol 17:391-398

Le Roux F, Audemard C, Barnaud A, Berthe F (1999) DNA probes as potential tools for the detection of Marteila refringens. Mar Biotechnol 1:588-597

> Leite RB, Afonso R, Cancela ML (2004) Perkinsus sp. infestation in carpet-shell clams, Ruditapes decussatus (L), along the Portuguese coast. Results from a 2-year survey. Aquaculture 240:39-53

Miyazaki T, Goto K, Kobayashi T, Kageyama T, Miyata M (1999) Mass mortalities associated with a virus disease in Japanese pearl oyster Pinctada fucata martensii. Dis Aquat Org 37:1-12

Ngo TTT, Choi KS (2004) Seasonal changes of Perkinsus and 
Cercaria infections in the Manila clam Ruditapes philippinarum from Jeju, Korea. Aquaculture 239:57-68

Paillard C (1992) Ethiologie et caractérisation de la maladie de l'anneau brun chez la palourde d'élevage, Ruditapes philippinarum. PhD thesis, University of Western Brittany, Brest

Paillard C (2004) A short review of brown ring disease, a vibriosis affecting clams, Ruditapes philippinarum and Ruditapes decussatus. Aquat Living Resour 17:467-475

Paillard C, Maes P (1995a) The brown ring disease in the Manila clam, Ruditapes philippinarum: I. Ultrastructural alterations of the periostracal lamina. J Invertebr Pathol 65:91-100

Paillard C, Maes P (1995b) The brown ring disease in the Manila clam, Ruditapes philippinarum: II. Microscopic study of the brown ring syndrome. J Invertebr Pathol 65:101-110

Park KI, Choi KS (2001) Spatial distribution of the protozoan parasite Perkinsus sp. found in the Manila clams, Ruditapes philippinarum, in Korea. Aquaculture 203:9-22

Park KI, Paillard C, Le Chevalier P, Choi KS (2006) Report on the occurrence of brown ring disease (BRD) in Manila clam, Ruditapes philippinarum, on the west coast of

Editorial responsibility: Eugene Burreson,

Gloucester Point, Virginia, USA
Korea. Aquaculture 255:610-613

> Perkins FO (1996) Shell disease in the gold lip pearl oyster, Pinctada maxima and the eastern oyster, Crassostrea virginica. Aquat Living Resour 9:159-168

Ponurovsky SK, Yakovlev YM (1992) The reproductive biology of the Japanese littleneck, Tapes phillipinarum (A. Adams and Reeve, 1850) (Bivalvia: Veneridae). J Shellfish Res 11:265-277

> Richardson CA, Ibarrola I, Ingham RJ (1993) Emergence pattern and spatial distribution of the common cockle Cerastoderma edule. Mar Ecol Prog Ser 99:71-81

Rungger D, Rastelli M, Braendle E, Malsberger RG (1971) A viruslike particle associated with lesions in the muscles of Octopus vulgaris. J Invertebr Pathol 17:72-80

Villalba A, Reece KS, Camino Ordas M, Casas SM, Figueras A (2004) Perkinsosis in molluscs: a review. Aquat Living Resour 17:411-432

Villalba A, Casas SM, Lopez C, Carballal MJ (2005) Study of perkinsosis in the carpet shell clam Tapes decussatus in Galicia (NW Spain). II. Temporal pattern of disease dynamics and association with clam mortality. Dis Aquat Org 65:257-267

Submitted: February 14, 2008; Accepted: May 27, 2008 Proofs received from author(s): July 7, 2008 